\title{
TOPO-EDAPHIC, VEGETATION COVER AND TYPE INFLUENCE ON SPATIAL DISTRIBUTION OF GULLIES IN SENGWA WILDLIFE RESEARCH AREA (SWRA), NORTH WEST ZIMBABWE
}

\section{Mahakata Innocent $^{1 *}$, Hungwe Christopher ${ }^{1 \& 2}$, Ngoni Mukome ${ }^{3}$, Matindike Spenser ${ }^{2}$, Gonhi Prudence ${ }^{2}$, Masumba Yvonne ${ }^{2}$ and Kudzai Mugogo ${ }^{4}$}

${ }^{1}$ Zimbabwe Parks and Wildlife Authority, Sengwa Wildlife Research Institute, Bag 6002, Gokwe, Zimbabwe.

${ }^{2}$ Chinhoyi University of Technology, Department of Wildlife Ecology and Conservation, Bag 7724, Chinhoyi, Zimbabwe.

${ }^{3}$ University of Zimbabwe, Department of Geography and Environmental Science, P.O Box MP 167, Mount Pleasant, Harare, Zimbabwe.

${ }^{4}$ Midlands State University, Department of Geography and Environmental Studies, Bag 9055, Senga, Gweru, Zimbabwe.

*Corresponding Author: innocentmahakata@gmail.com; Cell: +263716468098

Cite this article:

Mahakata I., Hungwe C., Ngoni M., Matindike S., Gonhi P., Masumba Y., Kudzai M. (2021), Topoedaphic, Vegetation Cover and Type Influence on Spatial Distribution of Gullies in Sengwa Wildlife Research Area (SWRA), North West Zimbabwe. African Journal of Environment and Natural Science Research 4(4), 61-73. DOI: 10.52589/AJENSRUO9BTEUX.

\section{Manuscript History}

Received: 23 Aug 2021

Accepted: 13 Sept 2021

Published: 3 Oct 2021

Copyright $($ ) 2020 The Author(s). This is an Open Access article distributed under the terms of Creative Commons AttributionNonCommercial-NoDerivatives 4.0 International (CC BY-NC-ND 4.0 ), which permits anyone to share, use, reproduce and redistribute in any medium, provided the original author and source are credited.
ABSTRACT: Gully erosion is a common phenomenon in arid and semi-arid areas and is mostly influenced by soil type, topography, vegetation type and cover. The objective of the study was to determine the effect of topo-edaphic, vegetation type and cover on gully occurrence, hence map their spatial distribution in SWRA. A conventional method was used where field visit to known gully sites was done. At each site, GPS points were marked at three points, that is, at the head site, the middle and lower end of the gully. Soil samples, gully width, depth, length, vegetation type and cover were recorded for each point where GPS coordinates were collected. GPS points were overlaid on SWRA processed vegetation, soil and topographic map for analysis on the spatial distribution of gullies. Fifty-six gullies were recorded with highly affected areas on the southwestern side of the park. Associated soils types were clay and loam of the Madumabisa mudstone, colluvial and alluvial located at altitudes below 1000 meters. Gully occurrences were sighted more in mopane dominated woodlands with few recorded in areas dominated by acacia woodlands and on the edges of miombo woodlands, which occupy the high grounds of SWRA. Gully length varied from $20 \mathrm{~m}$ in less developed gullies to $2520 \mathrm{~m}$ for mature gullies with volumes ranging between $52 \mathrm{~m}^{3}$ and $4649.4 \mathrm{~m}^{3}$. Hence, topography, soil type, vegetation cover and type influence gully location and occurrence. Future research should aim to monitor changes in gully development using remote sensing as it provides a great potential for monitoring gully changes across the landscape.

KEYWORDS: Gully, SWRA, Vegetation cover, Topography, Edaphic factors 


\section{INTRODUCTION}

A gully is defined as a miniature valley cut by concentrated runoff, but through which water commonly flows only during and immediately after heavy rains (Kotlyakov, 2010). According to Poesen (2003) gullies are recently developed drainage lines of temporary streams with steep banks and a nearly vertical gully head. Active gullies are characterised by a retreating head (Daba et al., 2003; Nyssen et al., 2006).

\section{Background}

Gullies are viewed as relatively permanent steep-sided watercourses that experience seasonal flows during the rainy season (Morgan, 1995). They can form in dendritic, linear, rather long, narrow and uniform. The size of gullies varies from shallow 0.3 to 1 meter deep gullies to over 20-meter deep ravine gullies (Dondofema, 2007). Gullies have normally a distinctive propagating head, which is a morphological expression between stable and unstable gully regimes and occurs where the overland flow from the catchment above enters the gully.

According to Milton (1971), activities at the uppermost headwall controls the development of a gully. Water running over the ground surface falls over the gully headwall, carving out undercuts and washing out fine material in plunge pools below. Where the wall is destabilized by undercuts and tension cracks, parts of the wall break off, are deposited within the gully and later washed out of the system. Rieke-Zapp and Nichols, (2011) mentioned that with progressing erosion, the head cut retreats upslope and continually enlarging the gully area.

Most gullies are formed due to a combination of hydrological and other environmental factors (Amare et al., 2019). Factors such as soil type, topography, rainfall, soil characteristics, profile characteristics and vegetation cover are considered the key determinants of the intensity and rate of gully advance (Zhao et al., 2019). Salleh and Mousazadeh (2011) mentioned soil type, topography and vegetation cover as key factors that influence gully formation in the semi-arid regions.

Topographic factors contribute to the erosion process and in most cases determined by the degree of the slope where a steeper slope results in increased velocity of runoff thereby initiating erosion (Jain and Goel, 2002; Valentin et al., 2005). A study by Seutloali et al. (2016) found that soil erosion occurs on steeper slopes that are greater than $30 \mathrm{~m}$. In contrast, Guanglu et al., (2004) found that shallow gullies that are 0.3-2 m deep generally occur on the lower and middle areas of the slope and rill erosion in the upper/ middle areas. Soil properties, such as texture, structure, moisture, roughness, and organic matter content that determine the soils aggregate stability (Vrieling, 2006).

Vegetation cover and type are important factors controlling soil erosion and can significantly decrease soil loss, due to its ability to bind soil particles, thereby protecting the soil (Jain and Goel, 2002). Good vegetation cover helps to reduce runoff impacts on soil (Luo et al., 2020). Erosivity is the ability of rainfall and runoff to cause soil detachment and transport. The ability of rain to cause detachment and transport is partly the result of raindrop impact, and partly due to the runoff that rainfall generates (Lal and Elliot, 1994). Vegetation cover plays a pivotal role in protecting the soil surface against erosion (Vrieling, 2006). It is defined as the fraction or percentage of the ground surface covered by vegetation (Purevdorj et al., 1998). 
Achten et al., (2008) note that gully erosion is one of the major problems affecting ecosystems integrity and their occurrence varies spatially. Continuation of gully formation in the ecosystem leads to a loss in ecosystem quality as a result of habitat fragmentation according to Desta and Adunga (2012). Dondofema (2007) highlighted several problems associated with gully formation which include loss of soil quality, degradation of the ecosystem and less capacity of the area affected to prevent natural disasters such as flooding. Gully erosion is geologically a widespread problem (Lal, 1992) and is common in semi-arid regions which are characterised by the denuded landscape. Frankl et al., (2020) pointed out that gully erosion is more difficult to control.

Gully erosion occurrence had been recorded extensively in SWRA especially in the northwest side of the park covering the Samapakwa area. One of the ecological challenges in SWRA is land degradation caused by gully erosion. Continued expansion of gullies in SWRA has contributed to the loss of soil and fragmentation of major ecosystems. However, information on explaining the influence of topo-edaphic and vegetation cover characteristics and gully erosion in SWRA is still rudimentary yet is important in monitoring spatial distribution and change in gully formation in SWRA, hence developing strategies to control their occurrence. The objective of the study was to determine the effect of topo-edaphic, vegetation cover and type on gully occurrence, hence map the spatial distribution of gullies in SWRA.

\section{METHODOLOGY}

\section{Study area}

The study was done in SWRA located in the Sebungwe region, north-western Zimbabwe (Figure, 1). The area lies between $28.803^{\circ}$ and $28.820^{\circ} \mathrm{E}$ and $18.801^{\circ}$ and $18.813^{\circ} \mathrm{S}$ and it covers a surface area of $373 \mathrm{~km}^{2}$. SWRA experiences three climatic seasons: a hot wet period from November to April, a cool dry period from May to July and a hot dry period from August to October (Mapaure and Campbell, 2002). The mean annual rainfall is $600 \mathrm{~mm}$, with a range from 346.6 to $1010 \mathrm{~mm}$, while the mean annual temperature is $23.6 \mathrm{C}$ with October being the hottest month and July the coldest. The altitude varies from about $808 \mathrm{~m}$ in the river valleys to about 1043 m on the Samapakwa plateau (Clifford et al., 2018). The geological formation has been dissected by three north-flowing major rivers, the Sengwa, Manyoni and Lutope, which dissect the sandstone escarpment into several sections. The surface geology comprises the lower and upper Karoo age. The lower area is represented by the Madumabisa mudstone formation weathering grey carbonaceous shale while the upper karoo overlies the mudstones which gave rise to geologically significant colluvial deposits with carbonaceous and siliceous matrices. The western side of the area experience high erosion as a result of the soil type and terrain. Major vegetation types include mopane woodland, riverine dominated acacia woodlands, miombo and Combretum bush. 


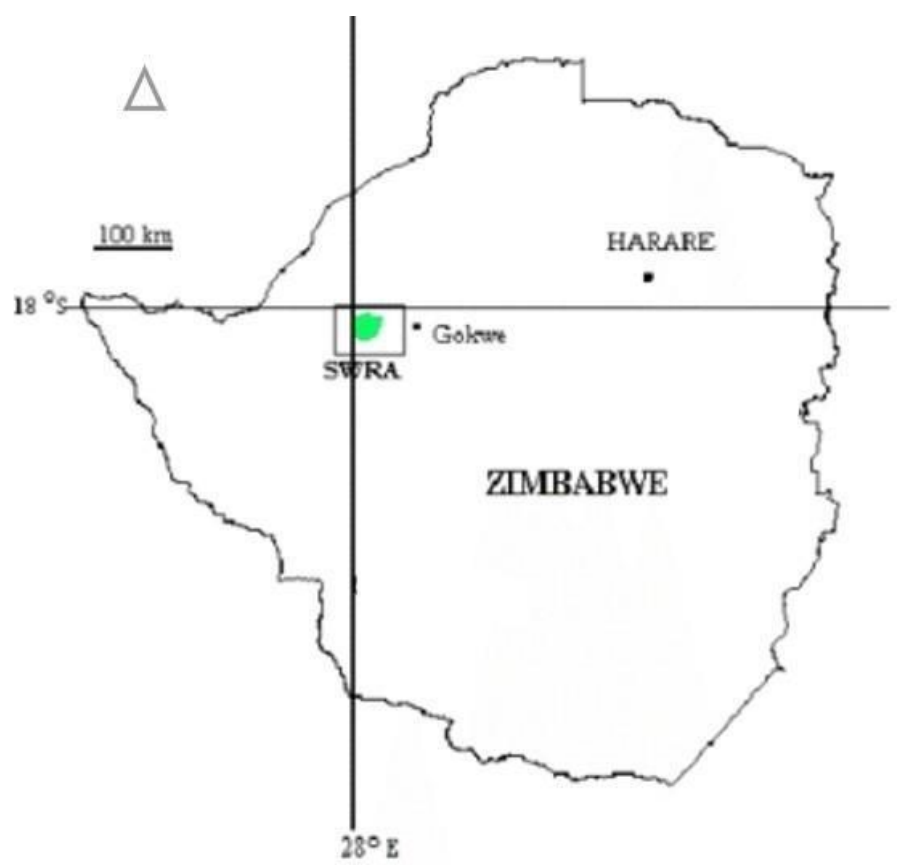

Figure 1: Location of SWRA and its drainage system in relation to topography.

\section{Data Collection}

In this study, direct measurement and observation at individual sites were done. All known gully sites were visited. Field data were collected from the $8^{\text {th }}$ of July to the $30^{\text {th }}$ of July, 2021 . Initially, data on known gully sites from Sengwa Wildlife Research Institute records were used to identify sites. Data collection was done using a handheld Etrex Global Positioning System (GPS) receiver to collect points. Gully dimensions i.e. length, width and depth were measured using a surveyor's 100 meters tape measure and 3 meters ranging poles for the estimation of gully volume, which is equivalent to the volume of soil lost. Gully dimensions were measured at three points that is the upper, middle and lower parts and then averaged to account for the change in topography. Gully depth was measured at the maximum deepest point of the gully coinciding with the measured upper, middle and lower parts. Soil samples, altitude, vegetation type and cover were also collected at three sites coinciding with the measured sites. It was assumed that the presence of gully erosion is possibly attributed to the drainage area and the amount of vegetation cover surrounding it. The slope was divided into three levels that is upper areas of ridges, steep areas and lower gentle areas usually occupying flat low lying areas. Vegetation cover was classified as bare, low, moderate, relatively high and completely covered. 


\section{Analysis}

The gully volume was estimated using the formula expressed in the equation below.

$\mathrm{V}=\mathrm{L} \times[(\mathrm{Wt}+\mathrm{Wb}) / 2] \times \mathrm{D}(1)$

Where: $\mathrm{V}$ is the volume in cubic metres; $\mathrm{L}$ is the total length in metres; $\mathrm{Wt}$ is the average top width in metres; $\mathrm{Wb}$ is the average bottom width in metres; $\mathrm{D}$ is the average depth measured in metres.

Percentage vegetation cover was visually estimated, using the method by Daubenmire (1959). $10 \times 10 \mathrm{~m}$ plots were demarcated to estimate percentage vegetation cover coinciding with the identified gully points where samples were collected. Soil samples collected were tested using a simple method by mixing water and soils in a small bottle and mark the percentage of sand, clay and silt to determine how much soil each site have. The soil texture triangle was then used to determine the dominant soil type for each area. Mapping was done in QGIS software on a raster map where GPS coordinates collected during sites visit were superimposed on a Digital Elevation Map (DEM) of the Sengwa area of $30 \mathrm{~m} \times 30 \mathrm{~m}$ which was downloaded from the USGS Earth Explorer website (http://earthexplorer.usgs.gov). GPS coordinates were overlaid on topographic, vegetation and soil maps of SWRA to determine distribution in relation to topography, soil and vegetation cover.

\section{RESULTS}

Small and less developed gullies were recorded around the Ntabamangwe area while the longest and mature gullies were recorded in the central-southern side of the park in areas to the west of Lutope River. Gully length varied from $20 \mathrm{~m}$ to $2520 \mathrm{~m}$ with width from $1.1 \mathrm{~m}$ to $4.2 \mathrm{~m}$ while depth ranged from $1.1 \mathrm{~m}$ to $3.5 \mathrm{~m}$. The volume of gullies measured varied from $52 \mathrm{~m}^{3}$ to $4649.4 \mathrm{~m}^{3}$ with deep gullies recorded in the Madumabisa mudstone and mostly U- shaped while small V-shaped gullies were recorded in the eastern side of the park.

\section{Topography and gully occurrence in SWRA.}

More gullies were recorded in the southern central area of the park. Their occurrence showed to be influenced by the type of terrain. All mapped gullies in SWRA occur at an altitude below $1000 \mathrm{~m}$ above sea level (Figure 2). No gullies in SWRA were recorded on top of ridges as well altitude above 1000m above sea level. Gullies recorded in the southern side of the park drained in the South East towards the Lutope River. 


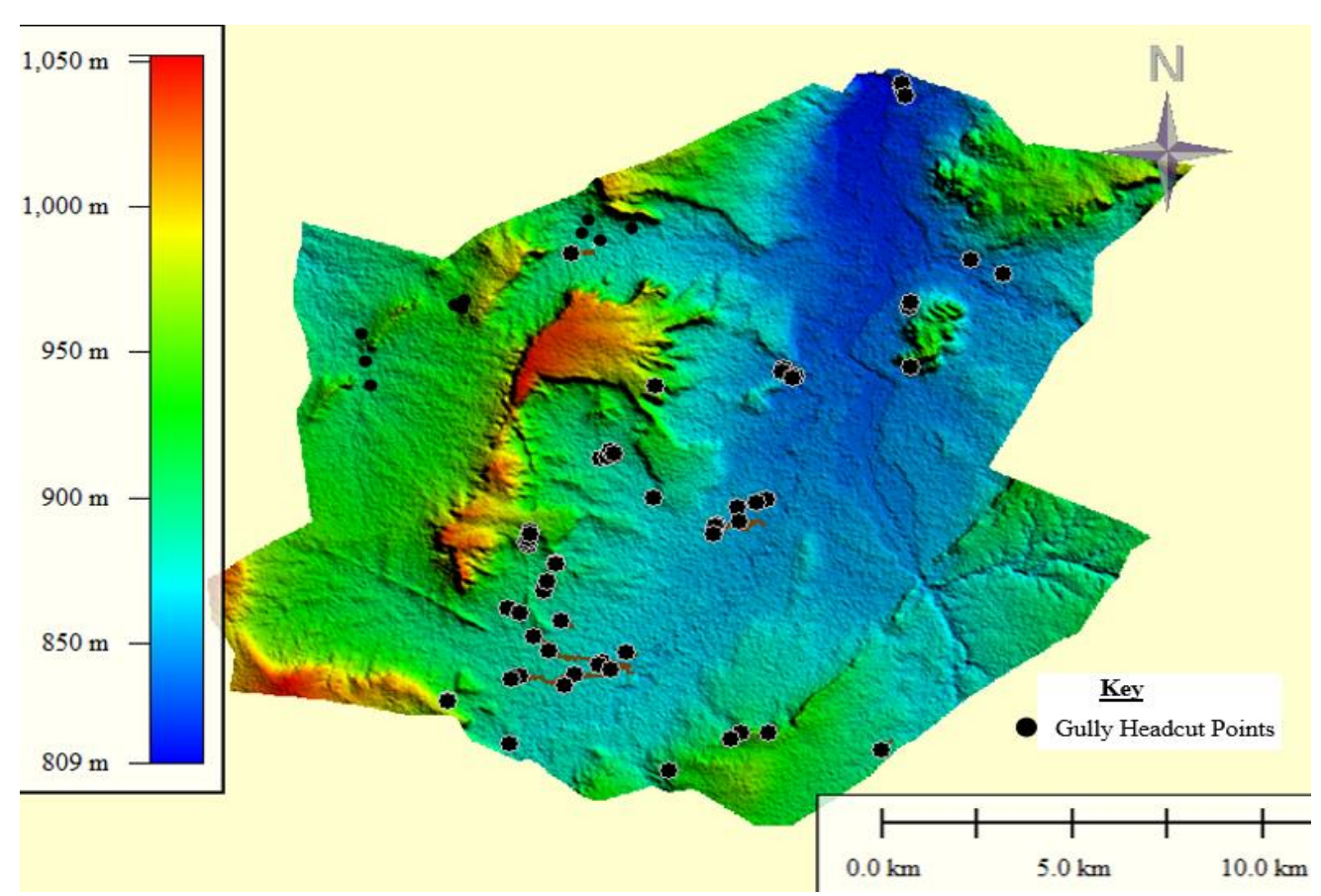

Figure 2: Map showing gully distribution points in relation to topography in SWRA.

Edaphic characteristics and gully occurrence in SWRA.

Gully occurrence in SWRA was found in areas dominated by clay soils of Madumabisa Mudstone, Colluvial and Alluvial soils located in low-lying areas (Figure 3).

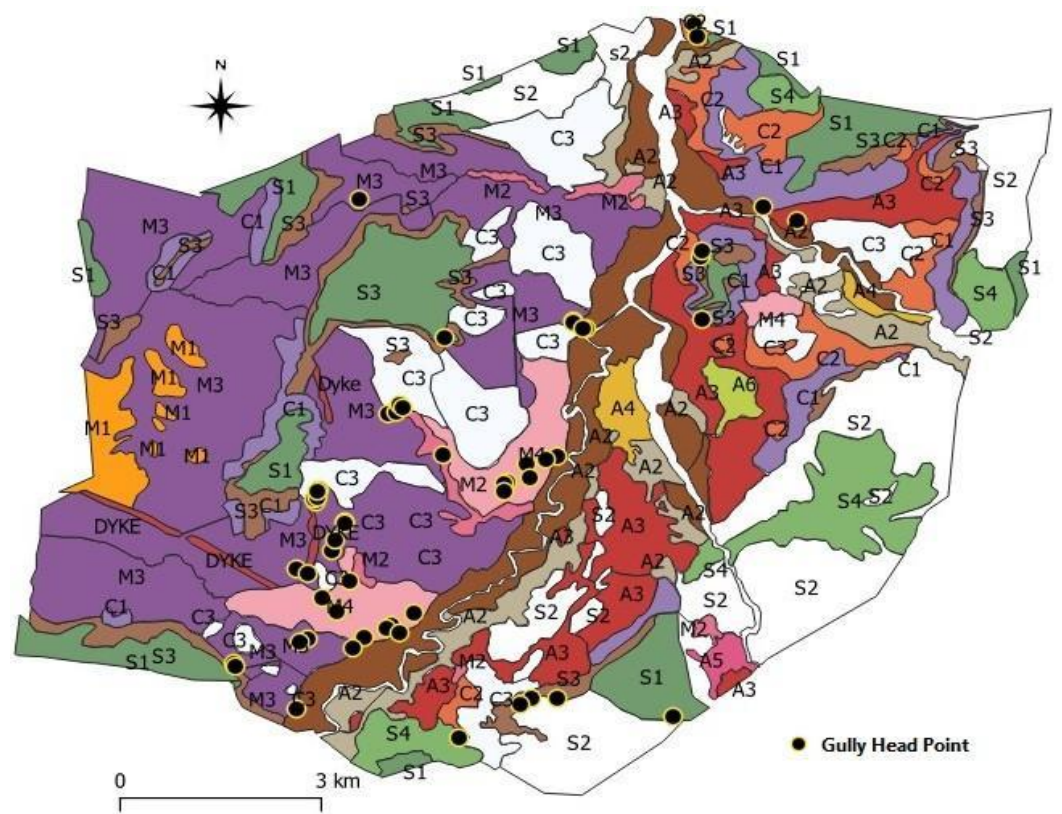

Figure 3: Map showing spatial distribution of gullies in relation to soil type in SWRA. (Major soil types of $S W R A S=$ Escarpment Grits, $M=$ Madumabisa Mudstone, $C=$ Colluvial, $A=$ Alluvial, $O / C=$ Rock Outcrops, $S M=$ Grit Mudstone, $D=$ Dolerite Dyke, $R=$ Undifferentiated Red Soils). 


\section{Vegetation type and cover influence on gully occurrence in SWRA}

Mapped gullies in SWRA were mostly recorded in areas associated with mopane dominated woodland with few gullies recorded in other vegetation types (Figure 4). The association with mopane woodland was a characteristic of sparse woodlands associated with bare grounds. No gullies were recorded in areas dominated by grasslands and in Baikiaea-Combretum thickets. Grasslands areas and Baikiaea-Combretum thickets have a good ground cover.

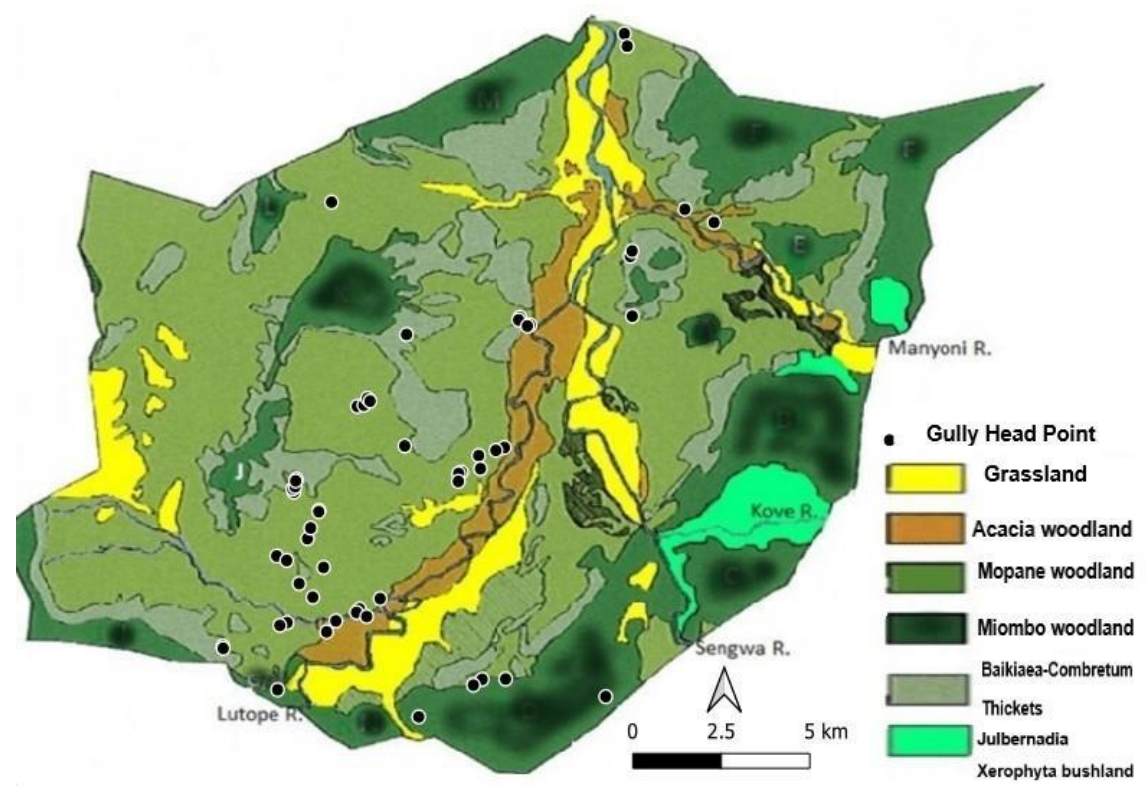

Figure 4: Map showing spatial distribution of gullies in relation to vegetation type in SWRA.

\section{DISCUSSIONS}

\section{Topography and gully occurrence in SWRA.}

Gully occurrence showed variation in relation to topographic factors and terrain for example in high areas (Top of ridges), middle areas (steep sides of higher areas) and lower sides (gentle to flat grounds located in low areas). Topography showed to play a pivotal role in concentrating water flow which influences gully development on steep sides of ridges. The survey indicated more gullies occur in the middle to lower gentle areas. Middle to low gentle areas have high flow accumulation and drainage with a large catchment area as well flow paths. The findings of this study agree with those by Descroix et al., (2008) who noted that gully growth preferred foot slopes and valley floors. These areas according to Beckedahl and Dardis (1988) represent areas where overland flow is focussed into ideal pathways of flow especially in concave hollows adjacent to drainage lines in deep soils.

Several authors (for example, Flügel et al., 2003; Kakembo et al., 2009) agree that gullies are mainly located on gentle slopes with gradients less than ten degrees. However, Tamene et al. (2006) found in Ethiopia that gully erosion is less severe on steep slopes, probably due to steep areas being less accessible and less exposed to wildlife activities and other disturbances. Poesen et al. (2003), explained that the critical drainage area needed for gully initiation decreases as 
the slope steepens while Kakembo et al. (2009) observed that gullying in several catchments of the Eastern Cape Province predominantly occur on gentle slopes where the critical drainage area or upslope contributing area is large.

The effects of topography were observed to be related to slope steepness and slope length. Kahalu (1994) mentioned slope is important when considering the overall transport of soil particles. As the slope steepens, the proportion of downslope movement increases due to increases in speed and size of surface runoff. Gentle slopes usually erode less, because there is more surface ponding and gentler flow which defend the surface against the impact of rain.

\section{Gully formation and soil type in SWRA}

The study revealed that gullies in SWRA are associated with Madumabisa mudstone, alluvial and colluvial soils. Madumabisa soil types are a characteristic of moderately deep to deep vertisols (Nyssen et al., 2002), while colluvial occur mostly in downslope. Alluvial soils are deep and highly sodic with layered profiles, hence easily affected by surface runoff. The results agree with findings by Mousazadeh and Salleh (2014) who highlighted that soil type play a big role in erosion and movement of particles which is influenced by erosion sensitivity.

According to Chaplot (2012), flow velocity overpowers a point of resistance of the soil materials, which initiates macro channel formation. According to Hudson (1989), the erosion process is a three-phase consisting of a detachment of soil particles from the soil mass and their transportation by erosive agents with successive removal of the eroded sediments into depressions, as influenced by geology or human activities. This process is faster in Madumabisa mudstone, colluvial and alluvial soils in SWRA compared to other soil types that exist in the area from personal observations.

Infiltrating precipitation and overland runoff increase soil weight and saturation. The added weight destabilizes the gully bank in areas associated with colluvial, alluvial and Madumabisa mudstone, hence could be the reason for reducing soil shear strength. According to Wijdenes et al., (1999), tension cracks affect gully bank instability as gully mass wasting processes are commonly followed by the existence of tension cracks. It was observed in semi-arid Kenya that tension cracks cause gully mass wasting by allowing more water into the cracks resulting in increased soil pore water pressure according to Wijdenes et al., (2001). This is a characteristic of Madumabisa mudstone and colluvial soils making them more prone to gully development in SWRA and other areas.

The study results contradict findings by Amare et al., (2019) who postulated that there is not specific soil type in which gully development does not occur but what varies is the size and form of the gullies in various soil types, arguing that major soil characteristics that govern mass-wasting after hydrology are soil strength, erosion resistance, type of soils and the type of soil deposits for example alluvium and colluvium. However, vertisols are the dominant types reported mostly for areas with valley bottom gullies. According to Tilahun, et al., (2014) vertisols create a good form for gully development and faster progress with subsequent gully formation. According to Nyssen et al., (2006), the high swelling and shrinkage nature of vertisols promotes the formation of gullies.

The primary soil characteristics associated with alluvium and colluvium deposits in the valley bottoms are greater depth (Mukai 2016) and low roughness and stoniness (Descroix et al., 2008). The low roughness and stoniness may ascribe to the valley bottom areas having well- 
sorted fine-textured alluvial and colluvium formations (Thomas et al., 2009). Because alluvium and colluvium deposited materials near the ground surface are generally unconsolidated and loose, they, coupled with other factors, may create a conducive situation for their erosion by water. Alluvium and colluvium deposits can also exhibit valley bottom lithological discontinuities across the soil profile. Such lithological discontinuities at the valley bottom, in turn, cause pipe occurrence, leading to gully formation and expansion (Ionita et al., 2015).

\section{Vegetation cover and type}

The study found that low vegetation cover areas favour gully erosion as this is where drainage lines converge and surface runoff is increased. These areas are mostly dominated by mopane woodlands which cover mostly the low laying areas of SWRA (Figure. 5a). The estimated vegetation cover within the catchment ranges where gullies recorded in SWRA have been classified as fairly bare to bare vegetation cover. A few gullies were identified in areas with high vegetation cover and these were a characteristic of acacia woodland along the riverine and at the edges of miombo woodlands that occur on high areas along Sianinga ridge. Short steep slopes, a common feature in the SWRA were noted to render the affected areas extremely susceptible to gully development bare areas with poor vegetation cover. In addition, large and well-developed U-shaped gullies were associated with low vegetation cover and bare grounds (Figure $5 \mathrm{~b}$ ) while moderate to high vegetation cover were associated with lower mean gully volumes of less than $418 \mathrm{~m}^{3}$.

Tamene et al. (2006) also found that gully erosion favour areas with low vegetation cover as they are more accessible to disturbances than areas with high vegetation cover. These findings were supported by Kheir et al. (2007) who reported that gullies mainly occur on gentle slopes where the upslope with relatively low soil cover. High soil loss was also noted to favour steep to gentle slopes characterised by bare grounds.

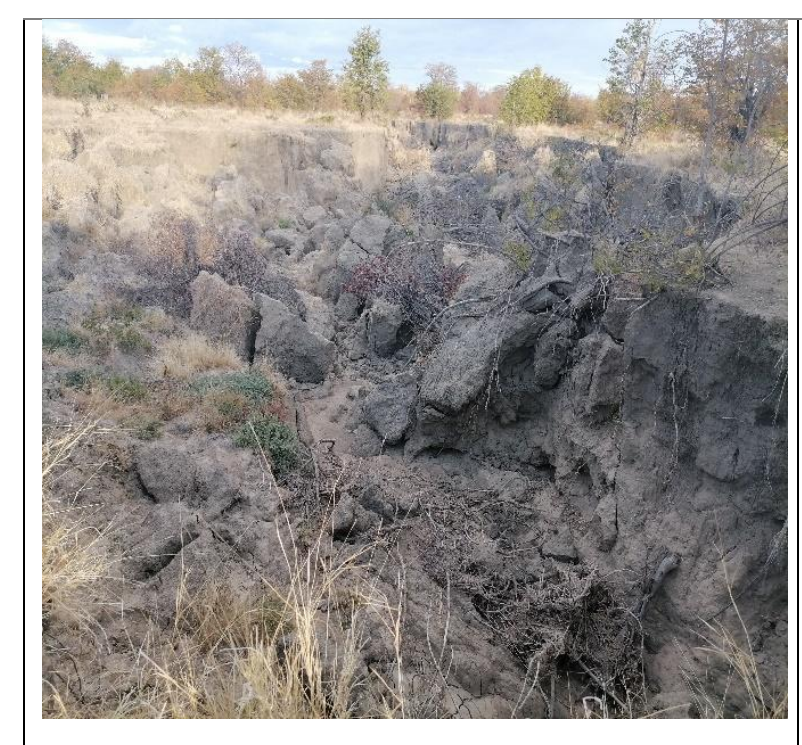

Figure 5a: Sparsed mopane woodland.

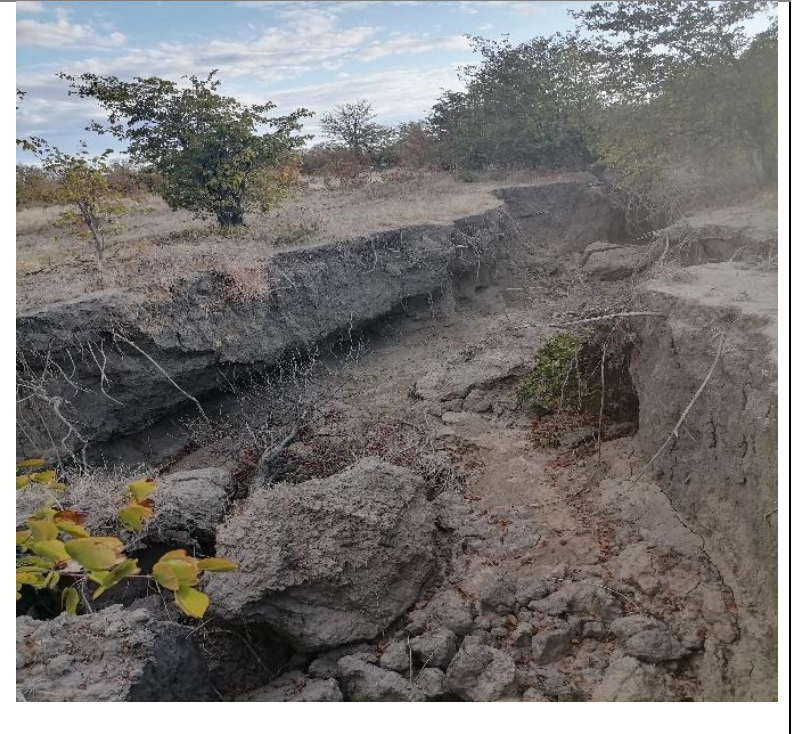

Figure 5b: U-shaped gully type in Lutope. 
Vegetation cover and type also influence the actual gully occurrence risks in SWRA. According to McPhee and Smithen (1984), the surface cover including mulch, gravel and canopy are effective to reduce surface runoff, hence minimise the chance of gully formation. According to Le Roux et al., (2008), good vegetation cover protects the soil from been prone to erosion even in steep gradients. Several studies carried out elsewhere indicated that reduction in vegetation cover is one factor that accelerates gully erosion in different areas (Tamene et al., 2006; Descroix et al., 2008). Hochschild et al., (2003) mention the impacts of paths and tracks in creating gullies that are associated with bare grounds.

\section{Spatial distribution of gullies in SWRA.}

In this study, results indicate gully occurrence vary spatially and are associated with Madumabisa sandstone, colluvial and alluvial soils mostly occupying low-lying areas of the park at an altitude below $1000 \mathrm{~m}$ above sea level. Gullies in the study area were observed along drainage lines which were formed in a network of gullies extending upslope. The western side of the park that is bounded by the western and northern boundary and the Sengwa and Lutope River recorded the highest number of gully development than any other area in the park. This could have been influenced by rugged terrains and several large surface water catchment areas. Vegetation type and covered showed influence on gully occurrence in SWRA. Mopane woodland-dominated areas are highly affected while few gullies were recorded on the edges of Miombo dominated woodlands along the edges of Sianinga Ridge. In low laying areas along the Lutope River, dominated by acacia woodlands, less developed gullies were also recorded.

\section{Implications for Research}

This research contributes to the scientific knowledge on explaining the influence of topography, soil type and vegetation type and cover on gully development in protected areas. This information is necessary to park managers and field ecologists in finding mitigation strategies to control further soil loss. It highlights the need to cooperate land rehabilitation in park planning for general ecosystem integrity.

\section{CONCLUSION}

The results of the study showed that gully development is influenced by topography, soil type and vegetation cover and this influence spatial distribution and occurrence in SWRA. Gully erosion with the associated soil loss favours steep areas to gentle slopes. The findings of this study should inform park managers of the need for rehabilitation of the affected areas to curb further developments.

\section{Future Research}

Future research should, therefore, aim to monitor changes in gully development using remote sensing as it provides a great potential for monitoring gully changes across a large scale. Other possible environmental variables that may have an influence on gully development needs to be researched as gully erosion is a multifaceted phenomenon influenced by numerous environmental variables. 


\section{Acknowledgement}

This project was made possible through assistance rendered by Sengwa Research Staff who helped in mapping and data collection during field visits. Special thanks go to the Zimbabwe Parks and Wildlife Management Authority for permission to publish the article.

\section{Declaration of interest}

The authors declare no conflict of interest.

\section{Project Funding}

No funding Grant was received for the project.

\section{REFERENCE}

Achten, W.M.J., Dondeyne, S., Mugogo, S., Kafiriti, E., Poesen, J., Deckers, J., Muys, B. (2008). Gully erosion in South-Eastern Tanzania: spatial distribution and topographic thresholds. Zeitschrift für Geomorphologie. DOI: 10.1127/0372-8854/2008/0052-0225.

Amare, S., Keesstra, S., van der Ploeg, M., Langendoen, E., Steenhuis, T., Tilahun, S. (2019). Causes and Controlling Factors of Valley Bottom Gullies. Land, 8, 141; doi:10.3390/land8090141

Chaplot, V. (2012). Impact of terrain attributes, parent material and soil types on gully erosion. Geomorphology 186, 1-11.

Clifford T, Patmore N, Stanley, Blessing K. Modifications of the Flora Zambeziaca in the Zambezi Basin by Environmental Antecedent Factors: Termites, Fire and Elephant. Int J Environ Sci Nat Res. 2018; 12(3): 555840. DOI: 10.19080/IJESNR.2018.12.555840.

Daba, S., Rieger, W., Strauss, P. (2003). Assessment of gully erosion in eastern Ethiopia using photogrammetric techniques. Catena 50(2-4), 273-291.

Daubenmire, R. F. (1959). A canopy-coverage method of vegetational analysis. Northwest Science, 33, 43-64

Descroix, L., Barrios, J.G., Viramontes, D., Poulenard, J., Anaya, E., Esteves, M., Estrada, J. (2008). Gully and sheet erosion on subtropical mountain slopes: Their respective roles and the scale effect. Catena. 72, 325-339.

Desta, L., Adunga, B. (2012). A Field Guide on Gully Prevention and Control. Nile Basin Initiative. Addis Ababa, Ethiopia. : www.nilebasin.org/entro.

Dondofema, F. (2007). Relationship between gully characteristics and environmental factors in the Zhulube Meso-Catchment: Implications for Water Resources Management. Master Degree thesis. Faculty of Engineering. University of Zimbabwe.

Flügel, W., Märker, M., Moretti, S., Rodolfi, G., Sidrochuk, A. (2003). Integrating geographical information systems, remote sensing, ground-truthing and modelling approaches for regional erosion classification of semi-arid catchments in South Africa. Hydrological Processes 17: 929-942

Frankl, A., Nyssen, J., Vanmaercke, M., Poesen, J. (2020). Gully prevention and control: Techniques, failures and effectiveness. Earth Surface Processes and Landforms/Volume 46 (1) 220-238. 
Guanglu, L., Klik, A. \& Faqi, W. (2004). Gully erosion features and its causes of formation on the (Yuan) land in the Loess Plateau, China. Gully Erosion Under Global Change. Sichuan Science and Technology Press. Chengdu, China, 131-142

Hochschild V, Märker M, Rodolfi G, Staudenrausch H. (2003). Delineation of erosion classes in semiarid southern African grasslands using vegetation indices from optical remote sensing data. Hydrological Processes 17: 917-928.

Hudson, N. W. (1989): Soil Conservation B.T. Batsford Limited, London.

Isaac N. Mapaure., Bruce M. Campbell (2002). Changes in miombo woodland cover in and around Sengwa Wildlife Research Area, Zimbabwe, in relation to elephants and fire. East African Wildlife Society, Afr. Ecology., 40, 212-219.

Jain, S. K. \& Goel M. (2002). Assessing the vulnerability to soil erosion of the Ukai Dam catchments using remote sensing and GIS. Hydrological Sciences Journal, 47, 31-40

Kahalu, C. (1994). The effects of slope length and inclination on the separate and combined actions of rain splash and runoff. In Conservation Soil Resources European Perspectives Rickson RJ Ed. University Press. Cambridge.

Kakembo, V., Xanga, W., Rowntree, K. (2009). Topographic thresholds in gully development on the hillslopes of communal areas in Ngqushwa Local Municipality, Eastern Cape, South Africa. Geomorphology, 110, 188-194

Kheir, R. B., Wilson, J. \& Deng, Y. (2007). Use of terrain variables for mapping gully erosion susceptibility in Lebanon. Earth Surface Processes and Landforms, 32, 17701782.

Kotlyakov, V.M. (2010). Natural Disasters. Encyclopedia of Life Support Systems. Volume 11. UNESCO.

Lal R, Elliot W. (1994). Erodibility and erosivity. In: Lal R (ed.). Soil Erosion Research Methods. St. Lucie Press: Delray Beach, Florida. 181-207

Lal, R. (1992). Restoring land degraded by gully erosion in the tropics. Advances in soil Science 17: 123-152.

Le Roux, J., Morgenthal, T., Malherbe, J., Pretorius, D., Sumner, P. (2008). Water erosion prediction at a national scale for South Africa. Water SA, 34, 305-314

Luo, J., Zhou, X., Rubinato, M., Li, G., Tian, Y., Zhou, J. (2020). Impact of Multiple Vegetation Covers on Surface Runoff and Sediment Yield in the Small Basin of Nverzhai, Hunan Province, China. Forests 11(329); doi: 10. 3390/f11030329.

McPhee, P.J., Smithen, A.A. (1984). Application of the USLE in the Republic of South Africa. Agricultural Engineering in South Africa 18: 5-13.

Milton, L.E. (1971). A review of gully erosion and its control. Soil Conservation Authority, Victoria.

Morgan, R.P.C. (1995). Soil Erosion and conservation - Second edition. Longman, p. 198

Mousazadeh, F., Salleh, K.O. (2014). The influence of lithology and soil on the occurrence and expansion of gully erosion, Toroud BASIN - Iran. Procedia Social and Behavioral Sciences 12, 749-756.

Mukai, S. (2016). Gully Erosion Rates and Analysis of Determining Factors: A Case Study from the Semi-arid Main Ethiopian Rift Valley. Land Degrad. Dev. 28, 602-615.

Nyssen, J., Poesen, J., Moeyersons, J., Haile, M., Deckers, J., Dewit, J., Naudts, J., Teka, K., Govers, G.; Veyret-Picot, M. (2006). Assessment of gully erosion rates through interviews and measurements: A case study from northern Ethiopia. Earth Surf. Process. Landforms, 31, 167-185. 
Nyssen, J., Veyret-Picot, M., Poesen, J., Moeyersons, J., Haile, M., Deckers, J., Govers, G. (2004). The effectiveness of loose rock check dams for gully control in Tigray, northern Ethiopia. Soil Use Manag. 20, 55-64.

Nyssen, J., Veyret-Picot, M., Poesen, J., Moeyersons, J., Haile, M., Deckers, J., Govers, G. (2004). The effectiveness of loose rock check dams for gully control in Tigray, northern Ethiopia. Soil Use Manag. 20, 55-64.

Poesen, J.J., Nachtergaele, G., Verstraeten., Valentin, C. (2003). Gully erosion and environmental change: importance and research needs. Catena 50(2-4), 91-133.

Purevdorj, T., Tateishi, R., Ishiyama, T., Honda, Y. (1998). Relationships between per cent vegetation cover and vegetation indices. International Journal of Remote Sensing, 19, 3519-3535.

Rieke-Zapp, D.H., Nichols, M.H. (2011). Headcut retreat in a semiarid watershed in the southwestern United States since 1935. Catena 87, 1-10.

Salleh, K.O., Mousazadeh, F. (2011). Gully erosion in semiarid regions. Procedia Social and Behavioral Sciences 19 (2011) 651-661.

Seutloali, K. E., Beckedahl, H.R., Dube, T., Sibanda, M. (2016). An assessment of gully erosion along major armoured roads in the south-eastern region of South Africa: remote sensing and GIS approach. Geocarto International, 31, 225-239

Tamene, L., Park, S., Dikau, R. Vlek, P. (2006). Analysis of factors determining sediment yield variability in the highlands of northern Ethiopia. Geomorphology, 76, 76-91.

Thomas, J.T., Iverson, N.R., Burkart, M.R. (2009). Bank-collapse processes in a valleybottom gully, western Iowa. Earth Surf. Process. Landforms 34, 109-122.

Tilahun, S.A., Guzman, C.D., Zegeye, A.D., Ayana, E.K., Collick, A.S., Yitaferu, B., Steenhuis, T.S. (2014). Spatial and Temporal Patterns of Soil Erosion in the Semihumid Ethiopian Highlands: A Case Study of Debre Mawi Watershed. In Nile River Basin; Springer Science and Business Media LLC: Berlin/Heidelberg, Germany. Volume 9783319027203, 149-163

Valentin, C., Poesen, J., Li, Y. (2005). Gully erosion: impacts, factors and control. Catena, 63, 132-153.

Vrieling, A. (2006). Satellite remote sensing for water erosion assessment: A review. Catena, $65,2-18$

Wijdenes, D.J.O., Bryan, R. (2001). Gully-head erosion processes on a semi-arid valley floor in Kenya: A case study into temporal variation and sediment budgeting. Earth Surf. Process. Landforms 26, 911-933.

Wijdenes, D.J.O., Poesen, J., Vandekerckhove, L., Nachtergaele, J., De Baerdemaeker, J. (1999). Gully-head morphology and implications for gully development on abandoned fields in a semi-arid environment, Sierra de Gata, southeast Spain. Earth Surf. Process. Landforms, 24, 585-603.

Zhao, B., Zhang, L., Xia, Z., Xu, W., Xia, L., Liang, Y., Xia, D. (2019). Effects of Rainfall Intensity and Vegetation Cover on Erosion Characteristics of a Soil Containing Rock Fragments Slope. Advances in Civil Engineering Volume 2019, Article ID 7043428, 14 pages https://doi.org/10.1155/2019/7043428. 